\title{
The Green Flings: Norwegian Oil and Gas Industry's Engagement in Offshore Wind Power
}

\author{
Tuukka Mäkitie, Håkon E. Normann, Taran M. Thune, and Jakoba Sraml Gonzalez \\ Centre for Technology, Innovation and Culture, University of Oslo, Norway \\ Post-print, Accepted in Energy Policy \\ https://doi.org/10.1016/j.enpol.2018.12.015
}

\begin{abstract}
Reorientation of fossil fuel industries towards renewable energy, and the role of changes in organizational environment underlying such processes, have not featured strongly in the study of sustainable energy transitions. We contribute to this important policy issue with a case study of the Norwegian oil and gas industry and its engagement in offshore wind power. We study how the engagement has changed during the period 2007-2016, and whether these changes correspond with developments in the industry's task and institutional environments. Our study reveals that despite relatively stable institutional environment and continuous growth in offshore wind market over the last decade, the oil and gas industry's engagement has fluctuated over time. These fluctuations - green flings - took place during two market downturns in the oil and gas market, while during an oil and gas boom the industry reoriented back to this core market. Our results draw attention to the potential importance of market changes for reorientation of fossil fuel industries towards renewable energy. We conclude by discussing the implications of our study for policies seeking to support sustainable energy transitions.
\end{abstract}




\section{Introduction}

The current hydrocarbon energy system rests on a large incumbent industry that has dominated the energy system of the world for more than a century. This industry, consisting of large oil and gas $(\mathrm{O} \& \mathrm{G})$ firms and their suppliers, has stakes in established value chains, technologies and business models. The industry around O\&G has therefore often been seen defending the established sociotechnical energy system based on fossil fuels against a transition towards sustainability and renewable energy (Newell and Paterson, 1998, Geels, 2014b).

Some recent studies, however, have shown that incumbent energy industries are also able to transform towards sustainability, and even drive innovation in renewable energy (Pinkse and van den Buuse, 2012, Bergek et al., 2013, Steen and Weaver, 2017). In countries with a large fossil fuel industry, reorientations towards renewable energy have high relevance for energy and industrial policy since it creates a potential for utilization of existing capabilities, technologies and experience in new markets. In Norway for instance, the $\mathrm{O} \& \mathrm{G}$ industry has influenced the development of an innovation system around offshore wind power (OWP) (Hansen and Steen, 2015, Mäkitie et al., 2018a). Renewable energy can therefore provide an opportunity for new economic development and employment by redeploying existing industrial resources. This is an attractive, and perhaps the most feasible, policy scenario towards a sustainable energy transition in countries with a substantial $O \& G$ industry.

Such reorientations of incumbent energy industries have thus far been little studied in discussion of sustainable energy transitions (Geels, 2018). It has nevertheless been argued that the environment of incumbent industries is an important source of pressure driving reorientation towards sustainability (Geels, 2014a, Penna and Geels, 2015). After all, it is the growing awareness in society regarding challenges such as climate change, which has had an important role in raising the need to de-carbonize the global energy system.

However, climate change concerns have not yet led to a radical transition in the incumbent energy industry. For instance, while several multi-national oil companies have decades ago acknowledged the 
climate change problem, their actions to tackle this issue have remained somewhat meagre. Even in Shell and BP, which historically have been some of the more receptive oil companies to climate change concerns, the actions have been limited to relatively small investments in renewable energy technologies and reduction of emissions in production processes (Kolk and Levy, 2001, van den Hove et al., 2002). Hence, while climate change is a key institutional issue for the incumbent oil and gas industry (Levy and Kolk, 2002), it has not yet caused a large-scale reorientation within this industry towards new and sustainable markets, such as renewable energy.

Meanwhile, even though public support for renewable energy technologies has arguably been an important vehicle to drive clean energy innovation (Jacobsson and Lauber, 2006), it is becoming apparent that such policy measures alone have not been enough to speed up the change at the pace required by the Paris Agreement (Scientific American, 2018). Hence, it is necessary to explore more extensive sets of energy policy to accelerate energy transitions (cf. Kivimaa and Kern, 2016). For instance, policies targeting the economic conditions in the core markets of the incumbent energy industries (such as fossil fuels) have received little attention, even though economic pressures have been reported to be effective in destabilizing fossil fuel paths (Turnheim and Geels, 2012).

The ambition of this paper is to contribute to the understanding of reorientations towards renewable energy in incumbent energy industries, and how this may be influenced by changing pressures and incentives in their environment. For this purpose, we study the engagement of the Norwegian O\&G industry in OWP in the period 2007-2016 in light of the developments in the (economic) task environment and the institutional environment of the industry (Scott, 2003). Our research questions are: How has the engagement of the oil and gas industry in offshore wind power changed over time, and has the engagement been consistent with the changing conditions in the organizational environment of the industry?

Our results draw attention to three potentially important and often over-looked issues related to understanding incumbent industries in energy transitions: the central role of the task environment for industry reorientation, the possible intermittent engagement in transitions, and the potential of 
redeployment of firm resources between fossil fuel and renewable energy markets. Consequently, our results also have implications for the study and policies of sustainable energy transitions. Our main argument is that changes in the task environment of incumbent energy industries, particularly in their core market, can be effective in increasing the pace of reorientation towards renewable energy.

In section two we discuss theoretical perspectives of our study, and the section three presents our empirical context. Section four explains the methodology of our study; section five presents the results. Section six discusses our results and suggests implications for policy.

\section{Theoretical perspectives}

Previous literature has shown that pressures and incentives from the environment can act as incentives and pressures for industries to transform (Tushman and Anderson, 1986, Geels, 2014a). We draw on literature from neo-institutional theory regarding organization-environment interaction as well as management literature regarding the role of market changes for resource redeployment across related markets. Finally, we synthesize these perspectives into an analytical framework.

\subsection{Organizational environment and industrial change}

Firms rely on their external environment for inputs such as resources and legitimacy, and for outputs such as markets for their products. Their actions are also influenced by the surrounding institutions such as regulations, norms and culture (Scott, 2014). Analytically, the environment of firms can therefore be divided into the (economic) task environment and the institutional environment, both of which can exert pressures and incentives for change (Scott, 2003).

Task environment consists of elements directly relevant for firms in executing their main tasks, i.e. revenue and value creation. The task environment consists of inputs (resources and materials) and outputs (markets) as well as the competitive and collaborative relationship with other actors, industries 
and technologies. Therefore, the task environment is of high importance for firms, and they seek to control this interface by arranging and coordinating firm activities to fit the prevailing conditions set by it (Scott, 2003). Examples of such measures are securing crucial resources (physical materials, financial and human capital etc.), and adapting firm strategies to ensure a favourable position in the marketplace. Changes in task environment, e.g. rapid market growth, a drop in the demand for the products of the firm, and the availability of qualified human capital, causes changes and uncertainty for firms (Suarez and Oliva, 2005). Therefore, changes in task environment shape the strategic decision-making of firms by posing pressures and incentives regarding competitiveness, efficiency and financial performance (Scott, 2003).

The institutional environment consists of regulative, normative and cultural-cognitive elements which promote and sustain the desirable conduct of firms (Scott, 2014). First, regulative features of institutional environment refer to the "rules of the game" and governance systems. To avoid penalties, firms tend to comply with relevant rules and laws. Second, normative features stand for the perceived appropriateness of firm behaviour and the commitment to following common values in the society. Firms are therefore socially obliged to follow expectations of "moral" behaviour in their relevant surroundings. Third, cultural-cognitive features refer to the shared symbolic systems, meanings and beliefs which guide the behaviour of firms, consciously or unconsciously. Such cultural-cognitive elements lead firms to mimic "orthodox" behaviour, derived from a taken-for-granted understanding of what is beneficial for the organization.

The respective institutional environment of firms shapes the legitimacy of firms in relation to the broader context of the society, consequently shaping the behaviour of firms (Scott, 2003, Scott, 2014). To stay legitimate, firms seek to conform to the surrounding institutions, and changes taking place in the institutional environment often lead to changes in firms (Mahon and Waddock, 1992). The institutional environment of firms is enacted, for instance, by government authorities, professional groups and society at large. Government organizations, for example, can introduce policies designed either to encourage or to hinder certain kinds of firm behaviour (Scott, 2003). 
In practice, the distinction between task and institutional environments is not clear-cut. For instance, technologies are shaped by social intentions and concerns, while markets are embedded in institutional foundations, e.g. in terms of regulations and practices (Pinch and Bijker, 1987, Fligstein and MaraDrita, 1996). Moreover, governing institutions have co-evolved with certain types of socio-technical systems, creating strong legitimacy for them, which is one of the reasons for carbon lock-in to environmentally harmful energy systems (Unruh, 2000). Hence, the division between task and institutional environments serves analytical purposes, but does not suggest an equally simple division in the real world.

\subsection{Industries and diversification}

We understand industries as organizational fields consisting of firms that produce relatively similar products or services, and firms that directly contribute to the value chain of those products and services (Scott, 2014). These firms embody various resources related to these operations such as know-how, production facilities, customer relations, and production and management capabilities (Penrose, 1959, Barney, 1991, Eisenhardt and Martin, 2000). Firms apply these resources to create value and revenue in a given industry, but they also often offer the basis for diversification to new markets.

Firms are more likely to diversify to related markets where they can redeploy their existing resources, for example, technology (Breschi et al., 2003), suppliers and customers (Nayyar and Kazanjian, 1993) or production capabilities (Carroll et al., 1996). Related diversification offers firms a possibility to realize synergies and complementarities between their operations in different markets (Tanriverdi and Venkatraman, 2005).

Besides offering new business opportunities, diversification can also act as an opportunity to reduce dependence on a single market, and enable firms to distribute resources between markets in different market situations. Bergh and Lawless (1998) suggest that large firms with low levels of diversification 
(i.e. firms focused on a single market) tend to invest in other markets when uncertainty in their core market grows. In other words, such firms often adapt to the uncertainty caused, for example, by downturns in demand by looking into other markets to secure revenue. Moreover, they are likely to exit from such alternative markets and refocus back to their core market if the uncertainty diminishes and opportunities there reappear (Bergh, 1998).

Resource redeployment between related markets carries less transaction costs due to for example the limited need to retrain or hire new staff and to reconfigure equipment to the needs of the new market. This helps the entry to a market, but also enables firms to reverse their engagement and refocus back to their core market (Sakhartov and Folta, 2015, Lieberman et al., 2017). Diversification to related markets can therefore act as a relatively easy reorientation strategy for firms facing uncertainty and diminishing opportunities in their core market.

Some firm resources are easier to redeploy than others. While firms may find it difficult to find alternative uses for their highly market-specific resources (e.g. purpose-built machines), generalpurpose resources (e.g. engineering and project management capabilities) may have more options for redeployment (Teece et al., 1997, Pisano, 2017, Thune and Mäkitie, 2018). Moreover, if resources are non-scalable, i.e. limited resources that cannot be used at the same time for different purposes (e.g. human resources, management attention), firms are likely to prefer the most profitable use of such resources, for example by deploying them in markets with relatively higher profits. Hence, when the commitment of firm resources in a market has an opportunity cost, firms are incentivised to redeploy non-scalable resources to the most attractive markets, amplifying the relevance of market changes in different markets. In contrast, resources that can be used for multiple purposes at the same time, i.e. scalable resources (e.g. patents and customer relationships), can be redeployed to new markets without such opportunity costs. Therefore, firms can redeploy scalable resources in new markets with less consideration of the relative importance of their markets (Levinthal and Wu, 2010, Wu, 2013, Mäkitie et al., 2018b). 


\subsection{Analytical framework}

Based on the above theoretical perspectives, we present our analytical framework in Figure 1. This framework suggests that changes in the task environment (especially commodity prices and other market conditions) and institutional environments (legitimacy and public policies) cause pressures (negative changes) and incentives (positive changes) for strategic decision-making of incumbent energy industries (cf. Penna and Geels, 2012, Turnheim and Geels, 2012, Mignon and Bergek, 2016). We focus on one type of response to changes in the environment: diversification through redeployment of resources from fossil to renewable energy markets. We acknowledge that firms can choose to refocus to their core market if the pressures and incentives for diversification disappear. Such redeployment behaviour is amplified in the case of the energy markets, where periods of high commodity prices in hydrocarbons can offer lucrative market opportunities in comparison to renewable energy markets, characterized by lower profit margins.

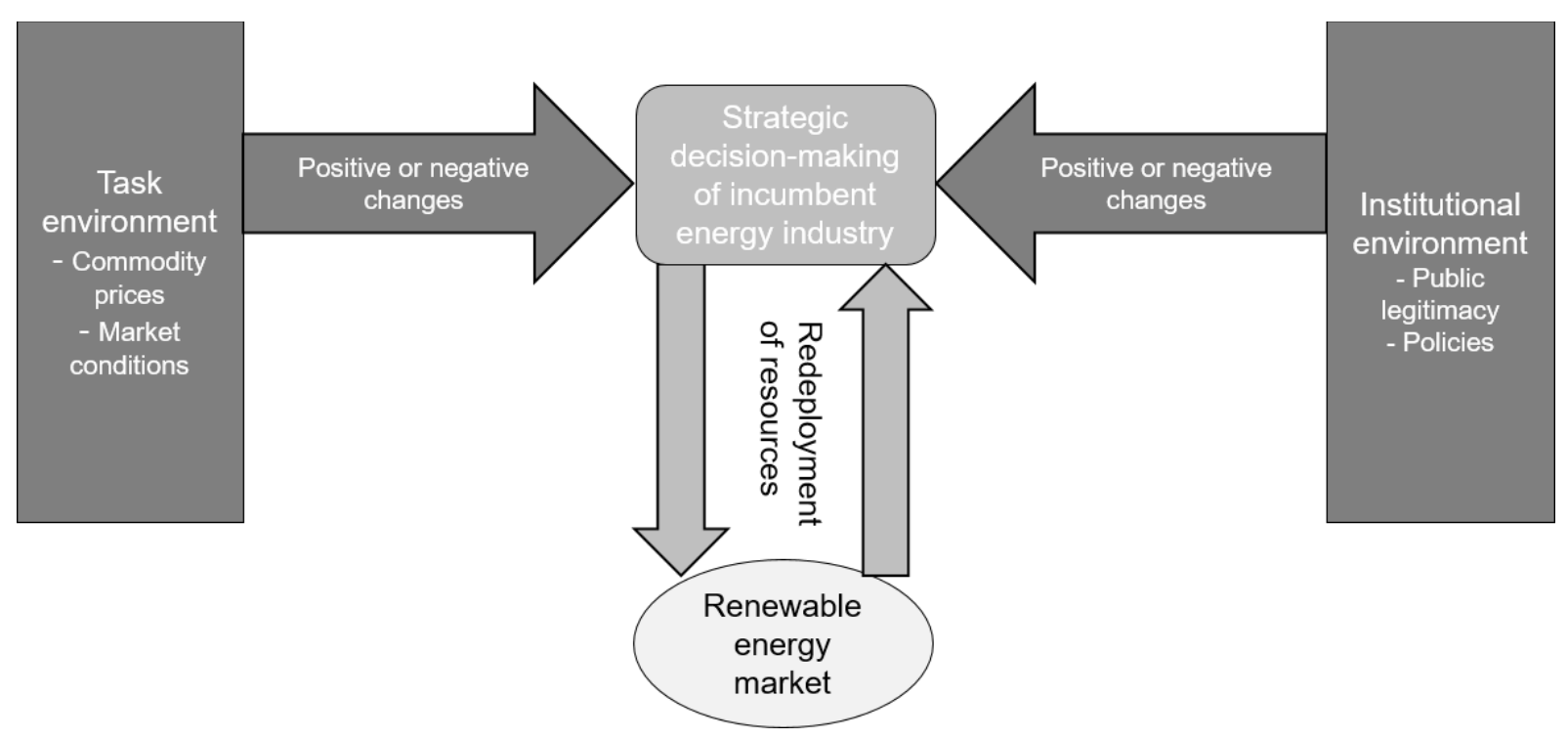

Figure 1 Analytical framework ${ }^{1}$

\section{Empirical context}

\footnotetext{
${ }^{1}$ We gratefully acknowledge the constructive suggestions of the anonymous reviewer in specifying the illustration of our analytical framework.
} 
Upstream O\&G industries are complex industrial sectors oriented towards identification, extraction and production of hydrocarbons in offshore conditions (Thune et al., 2018). Extraction of offshore petroleum resources requires high investments of capital, equipment and knowledge. Key companies are the O\&G companies (such as Shell, BP and Equinor), which are responsible for this task. The industry is disintegrated, meaning that sub-contractors or suppliers to the $O \& G$ companies perform most of the activities related to extraction. These suppliers closely follow the behaviour of the O\&G companies, as the investment decisions of O\&G firms signify the demand for the suppliers' services and products (Acha and Cusmano, 2005, Perrons, 2014). In Norway in 2014, between 1500 and 2000 Norwegian companies, and around 300000 employees, directly or indirectly, belonged to this industry (Blomgren et al., 2015). Only a few of these companies (less than 100) were O\&G firms, while the rest were various supply and service companies.

The investments and other strategic decision-making by $\mathrm{O} \& \mathrm{G}$ companies depend on several factors. Oil price is an important economic factor as it defines the viability of projects and profitability of investments. With higher oil prices, O\&G companies are prone to explore in newer and riskier areas (Mohn and Misund, 2009). In periods of low oil prices, O\&G companies tend to restructure and reduce costs to keep the productivity and profitability of oil extraction, and avoid more cost-intensive production fields (Grant, 2003). Hence, a drop in oil price triggers lower investments, while high prices eventually encourage further investments (Tvedt, 2002), making the industry cyclical with frequent up- and downturns.

The behaviour of O\&G companies is also influenced by other factors, such as geopolitical turbulence, prospects of licensing rounds, the number of sanctioned projects, new discoveries, technological change, and policy (Tvedt, 2002, Mohn, 2010, Dahl and Osmundsen, 2014). This suggests that the task and institutional environments jointly influence the strategic behaviour of O\&G companies and the evolution of the upstream O\&G industry (cf. Sraml Gonzalez, 2018).

Some O\&G companies have deployed resources in non-oil markets, including in developing renewable energy technologies such as solar, hydrogen, wind and biofuels (Kolk and Levy, 2001). In 
the case of solar PV-panels, the engagement of O\&G firms was often related to changes in the task environment in the $\mathrm{O} \& \mathrm{G}$ market and changing approaches in addressing the climate change problem (Pinkse and van den Buuse, 2012). In the case of Thailand, the engagement of O\&G companies in biofuels was linked to its similarities in the core $O \& G$ operations but additionally to the national socio-political rationales (Chaiyapa et al., 2018).

O\&G and OWP industries have technological similarities in terms of offshore and sub-sea techniques, i.e. it involves constructions and installations below and above sea-level. For instance Equinor, former Statoil, has been able to use their existing O\&G competences in their engagement in OWP and carbon capture and storage markets (Nilsen, 2017). Additionally, supplier firms in the value chain segments related to engineering, foundations, logistics and surveying in OWP have been able to draw upon their previous experience in O\&G (Normann and Hanson, 2015). A recent study showed that almost $80 \%$ of firms in Norwegian OWP industry based their operations in O\&G experience, and $86 \%$ of diversified firms in OWP were able to use their experience from the O\&G market with limited changes (Normann and Hanson, 2018). Moreover, Hansen and Steen (2015) have suggested that the diversification of Norwegian O\&G industry firms to OWP has been motivated by the opportunity to fill in 'gaps' in contracts in the more profitable, but cyclical, O\&G market.

\section{Methodology}

We have investigated the engagement of the Norwegian $O \& G$ industry ( $O \& G$ firms and suppliers) in the international OWP market in the period 2007-2016. We chose to begin our analysis from 2007 as this was the year when we first were able to see multiple firms in the O\&G industry engaging in OWP. We traced the activities of the O\&G industry firms over time to see whether the level of engagement in diversification followed changes in the task and institutional environments of the industry. In order to analyse such context-dependent processes, our empirical work comprised of a case study. We focused our analysis on the processes taking place in the domestic environment, but were also mindful 
of the important developments taking place on a global level. We adopted a process-study approach (Van de Ven, 2007, Langley, 1999), and used a combination of a qualitative and quantitative methods. The process of data collection and analysis had six steps.

As the first step in the analysis, we sought to identify all Norwegian O\&G industry firms that had diversified to OWP by 2015 . We gathered data from industry reports, industry and cluster organization memberships, 4C database and desk research. We concluded with 107 diversified firms (Mäkitie et al., 2018a).

In the second step, we collected data regarding these firms' engagement in OWP. The data consisted of mostly secondary sources, as this enabled an analysis of the full population of the known 107 diversifiers. Secondary data thus provided us a more complete picture of the level of activities in the industry. The main source of data was the Atekst/Retriever media database of five major Norwegian news media reporting on the O\&G industry: Dagens Naringsliv, Teknisk Ukeblad, Sysla, Offshore, and Petro. We performed individual searches involving the 107 firms together with two Norwegian words for OWP ("havvind" and "offshore vind"). In total, we analysed 698 news articles published between 2007 and 2016 to find details regarding the engagement in OWP. Moreover, we gathered news data, press releases and annual reports from firm websites when this data was available for the whole study period. We complemented the gathered secondary data with primary data from a survey which had enquired when Norwegian OWP firms had entered the market, and whether they considered O\&G as their primary market (response rate 109/183: 60\%, for details see Normann and Hanson, 2015).

All in all, we found data regarding the OWP engagement of 75 O\&G industry companies. The firms consisted mostly of supplier companies, and one O\&G company: Equinor. We categorized the activities in OWP as engagement incidents, where each incident contained information about the firmspecific activities in the OWP market, i.e. the name of the company, the time of the incident, a representative text excerpt data when available, and a written description of the incident. Later on, any 
duplicate descriptions of same incidents were removed. Finally, our database consisted of 241 unique incidents of OWP engagement.

In the third step, we used this data material to further describe the engagement of the O\&G industry as sequences of events taking place throughout our study period (Van de Ven, 1992). To assist in this process, we used three codes to categorize the engagement incidents: 1) statements of interest, 2) investments, and 3) contracts in OWP. This way we could evaluate the 'depth' of engagement. "Statements" were incidents where the firm had made a public statement regarding their interest and entry into the OWP market. Because such statements did not necessarily entail concrete commitments, we saw these as the 'weakest' form of engagement in OWP. The "investments" code stood for investments in future capabilities in the OWP market such as R\&D projects, facilities or specialized OWP companies. "Contracts" were seen as the strongest form of engagement in OWP, and described incidents where firms had sold their services and products in the OWP market. Finally, we defined important industry-level events taking place by identifying patterns and linkages between individual incidents. Each incident could be part of one or more events. Distinguishing between events and types of engaged companies provided us with a detailed overview of our study object over time.

In the fourth step, we collected data and described the developments and main events in the task environment of the industry, including both O\&G and OWP markets. We chose to measure uncertainty and increasing pressures in the task environment as negative developments in the core O\&G market. Positive developments in the market, on the other hand, we understood as incentives and reduced uncertainty in the task environment. We used two main quantitative indicators to describe the developments in the O\&G market: average annual price for Brent oil per barrel, and investments in Norwegian Continental Shelf (NCS) by O\&G firms. To enable a comparison of our task environment indicators with the engagement incidents, we normalized the datasets by calculating the z-score of each variable $(\mathrm{x})$ by using the population mean $(\mu)$ and the standard deviation $(\sigma)$.

$$
Z=\frac{x_{i}-\mu}{\sigma}
$$


In terms of the OWP market, we used data regarding the installed capacity and investments in OWP in Europe, as well as previous academic literature and industry reports from Wind Europe to track down main developments. We interpreted growth in the OWP market as an incentive for entry for firms with redeployable resources.

In the fifth step, we analysed changes in the institutional environment in terms of public legitimacy and policy in O\&G and OWP in Norway. We used the Atekst/Retriever tool to gather data of different framings of the O\&G industry in news media. We searched news articles in six Norwegian newspapers: Aftenposten, Verdens Gang, Adresseavisen, Dagbladet, Morgenbladet and Klassekampen. To compile indications of negative public legitimacy of the industry, we tracked the attention given to the topics of climate change and transitions in the context of the $O \& G$ industry. For the climate change framing, we searched the Norwegian equivalent of "climate change" in the same news articles using any of the sixteen Norwegian synonyms for O\&G industry, while the transition framing included the Norwegian words for "transition", "phasing out" and "after oil", together with "O\&G industry". We also searched for news about the O\&G industry with economic framings which is commonly used by the Norwegian O\&G industry in legitimizing itself in public debate (Ihlen and Nitz, 2008), and therefore understood as signalling positive legitimacy. As search terms, we used "O\&G industry" together with "jobs", "employment" and "welfare".

It should be noted that in above framings we only included the number of news articles and did not perform a detailed analysis. Therefore, we used this data as a measure of attention to important topics in the public legitimacy of the O\&G industry. Additionally, we also drew upon key policy documents, news stories and previous studies on the topic (especially Normann, 2015, Normann, 2017). This way 
we were able to complement the above quantitative measures with a qualitative description of the main events in the institutional environment.

We summarize the concepts, indicators and data from above steps in Table 1.

Table 1 Concepts, indicators and data

\begin{tabular}{|l|l|l|l|}
\hline Object of analysis & Definition & Indicator(s) & Data sources \\
\hline Task environment & Material-resource environment & Brent oil price & Statistics Norway \\
& $\begin{array}{l}\text { consisting of inputs (resources) } \\
\text { and outputs (markets) of the } \\
\text { O\&G industry }\end{array}$ & Investment levels in the O\&G & Petroleum Directorate \\
& Regulative, normative and & Legitimacy of O\&G industry & Wews data (6 newspapers) \\
\hline Institutional & cultural-cognitive environment & Policies & Policy documents \\
& of the O\&G industry & Prior studies \\
\hline OWP Engagement & The degree of activities of the & Engagement incidents of the & News data (5 industry media) \\
& O\&G industry firms in OWP & O\&G industry firms in OWP & Annual reports \\
& \multicolumn{2}{|l}{ (3 categories) } & Firm news \\
\hline
\end{tabular}

In the last step, we combined the three dimensions of the analysis (task environment, institutional environment, OWP engagement) into a joint timeline illustrating the process of the O\&G industry engagement in OWP within the context of task and institutional environments. We divided this overall development into a sequence of phases. We identified significant changes in our seven quantitative data sources (OWP engagement incidents, Brent oil price, O\&G investments in NCS, European OWP instalments, attention to economic, transition and climate change framings), distinguishing between different phases. We normalized the data sources by defining significant change as $40 \%$ of the overall range of the respective data series values. We then identified years where there was a significant change from the previous year in two or more indicators: these years were 2009, 2011 and 2015, resulting in four phases. This division into phases helped us to analyse how developments in the three dimensions of our analysis unfolded in relation to each other. However, such an analytical approach 
remained limited in establishing the causality between indicators, and it rather illustrates cooccurrences of events. In our final section, we discuss these co-occurrences in the light of our conceptual framework, and suggest possible explanations for the behaviour observed.

\section{Results}

\subsection{The engagement of O\&G industry in OWP in 2007-2016}

Figure 2 presents the number of engagement incidents of the O\&G industry in OWP over time, divided into four phases as indicated by the vertical lines. The four phases are marked by growth or decline in the number of engagement incidents observed (as described above). From the initial "Buildup phase", there was a significant growth in the number of incidents in 2009 and 2010, called "the first wave of engagement" of the O\&G industry in OWP. However, the growth in activities did not continue in the period 2011-2014 which we refer to as "the stagnation phase". Nevertheless, 20152016 had again more engagement incidents, and we call this phase as "the second wave of engagement”. Below we explain further the incidents and events behind these numbers.

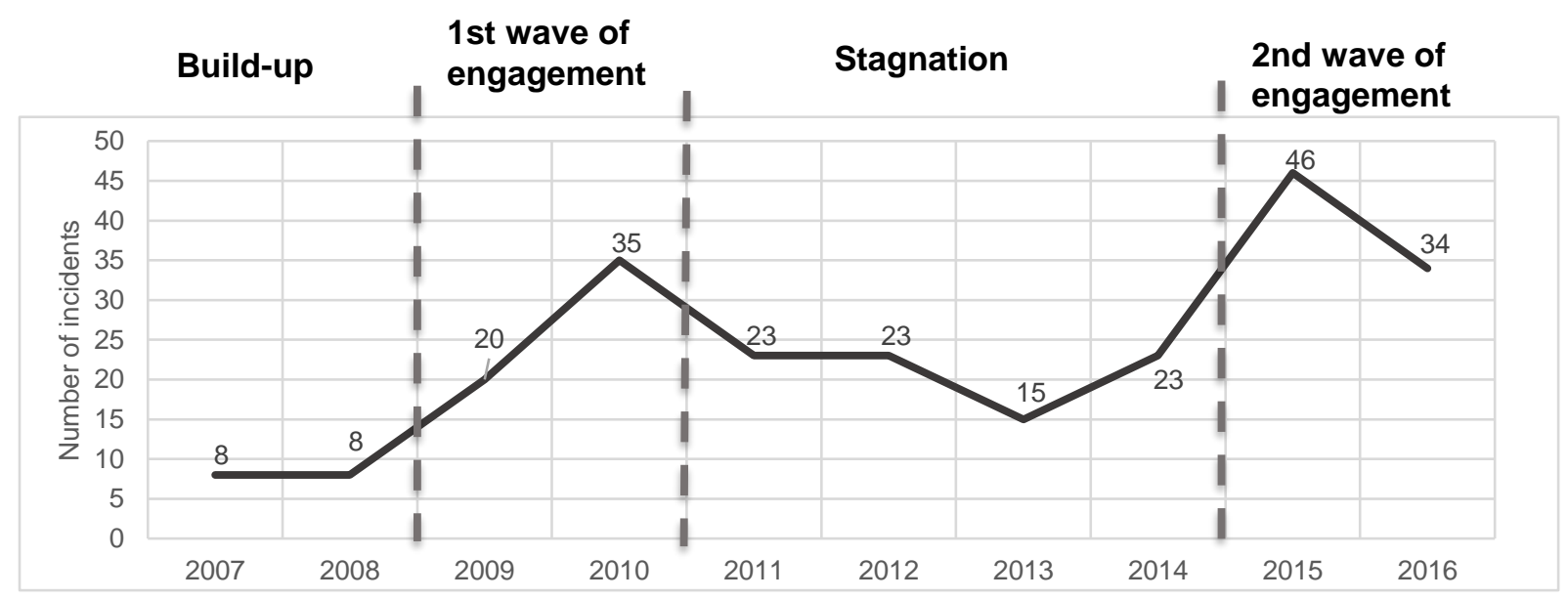

Figure 2 The engagement of Norwegian oil and gas industry firms in offshore wind power

\subsubsection{The build-up phase}

In the beginning of the 2000s, several Norwegian companies started to develop products for OWP.

These firms included small start-ups such as Sway but also Norsk Hydro, one of the largest Norwegian 
industrial companies. However, 2007 and 2008 an increasing number of O\&G industry companies started looking at opportunities in OWP. Important motivations to enter OWP were, for instance, expectations of an international market growth in OWP and the opportunities to redeploy existing competences. The build-up phase was characterized especially by $R \& D$ in floating concepts (i.e. deep water OWP turbines) of Hywind and Sway. In 2007, Statoil merged with Norsk Hydro, and the newly formed company made a strategic decision to include renewable energy as a part of their operations. In relation to this, the company decided to commence a demonstration project for Hywind turbine, originally developed by Norsk Hydro. In 2008, Statoil also established itself as an OWP park operator, and was given the consent for its first OWP park - the Sheringham Shoal in the UK. Such events attracted attention in the media and industry, and the involvement of a large player like Statoil created expectations for further growth in OWP.

Seen overall in our dataset, the OWP incidents consisted mainly of eight statements of interest in OWP, five investments, and three contracts.

\subsubsection{The first wave of engagement}

Rapid growth in engagement was seen in 2009 and 2010. Several O\&G industry firms entered into competition for contracts in the European OWP market, often citing expectations for future market opportunities as a motivation. For instance, AF and Dr. techn. Olav Olsen, seeking to utilize their existing offshore competences, invested in an OWP start-up called ViciVentus. Draka invested in a new cable production facility to power OWP parks. Meanwhile, Fred. Olsen, a pioneer firm in OWP since early 2000s, receiving concessions for OWP farms in Scotland and Ireland.

In 2010, some of the first major contracts took place. Aker Verdal, struggling after the financial crisis with few orders from the O\&G market, signed a contract to supply steel jacket foundations to the Nordsee Ost OWP farm in Germany. Moreover, maritime companies such as Seaproof Solutions and Parker Maritime received contracts for installing OWP parks. Also Draka's earlier investment in a new production unit started to pay off as the firm received its first OWP cable contract in November 
2010. The engagement in OWP in this phase consisted largely of statements of interest (26 in total), while we also found 16 incidents of investments as well as 13 contracts.

\subsubsection{The stagnation phase}

During the period 2011-2014, the engagement of the O\&G industry in OWP stagnated, as illustrated in Figure 2. While some firms continued to invest in competence and capacity building, fewer firms decided to enter the OWP market. Moreover, some existing OWP projects began to experience difficulties. While Sway celebrated the installation of a prototype of its floating turbine, the company struggled to find customers, and eventually declared itself bankrupt in 2014. Aker Verdal, on the other hand, experiencing financial losses in its Nordsee Ost project, managed to secure contracts in the newly recovered O\&G market, thus discouraging further activities in OWP (Steen and Karlsen, 2014). However, the few firms who did decide to enter this market seemed to be able to establish a foothold in the OWP market relatively quickly. For instance, maritime companies like Simon Møkster and Siem Offshore invested in OWP installation vessels. Moreover, a handful of companies, such as Fred. Olsen and Seaproof Solutions secured contracts to install OWP turbines, while Fjellstrand and Island Offshore were awarded contracts to deliver OWP vessels. The incidents in 2011-2014 consisted of 29 statements, 27 investments, and 28 contracts.

\subsubsection{The second wave of engagement}

The year 2015 was another turning point in the engagement in OWP as the number of incidents doubled from the previous year. Especially maritime firms were able to obtain several contracts in the OWP market. The earlier investments of Siem Offshore and Simon Møkster helped them to secure several installation and service contracts in European OWP parks. Fred. Olsen acquired similar contracts in the United States. Fjellstrand even decided to remodel one of their O\&G support vessels for OWP use. Moreover, Ulstein invested in developing a ship design tailored for OWP use, and also received contracts for delivering OWP vessels. As reasons for this engagement, firms commonly referred to opportunities to utilize O\&G competences while growing "another leg to stand on" in the OWP market. Meanwhile, Statoil raised its stakes by building the first floating wind power park in the 
world in Scotland; it also increased its presence in other OWP parks such as the Dogger Bank in the UK and Arkona in Germany. In addition, Statoil planned to build an OWP park outside New York. The engagement incidents consisted of 10 statements, 23 investments, and 47 contracts.

\subsubsection{Summary of OWP engagement in 2007-2016}

Seen over time, the engagement of the O\&G industry in OWP has increased and has gradually moved from statements of interest to more concrete activities such as contracts. Meanwhile, as Figure 2 clearly illustrates, the engagement has fluctuated considerably. In the following sections, we describe changes in the environment of the Norwegian O\&G industry, which help to explain this phenomenon.

\subsection{Developments in the task environment}

\subsubsection{The O\&G market}

To contextualise the events just described, Figure 3 adds information about key developments in the

O\&G market by illustrating changes in oil price and investment levels on NCS from 2007 to 2017.

Both indicators influence the behaviour of the $O \& G$ industry.

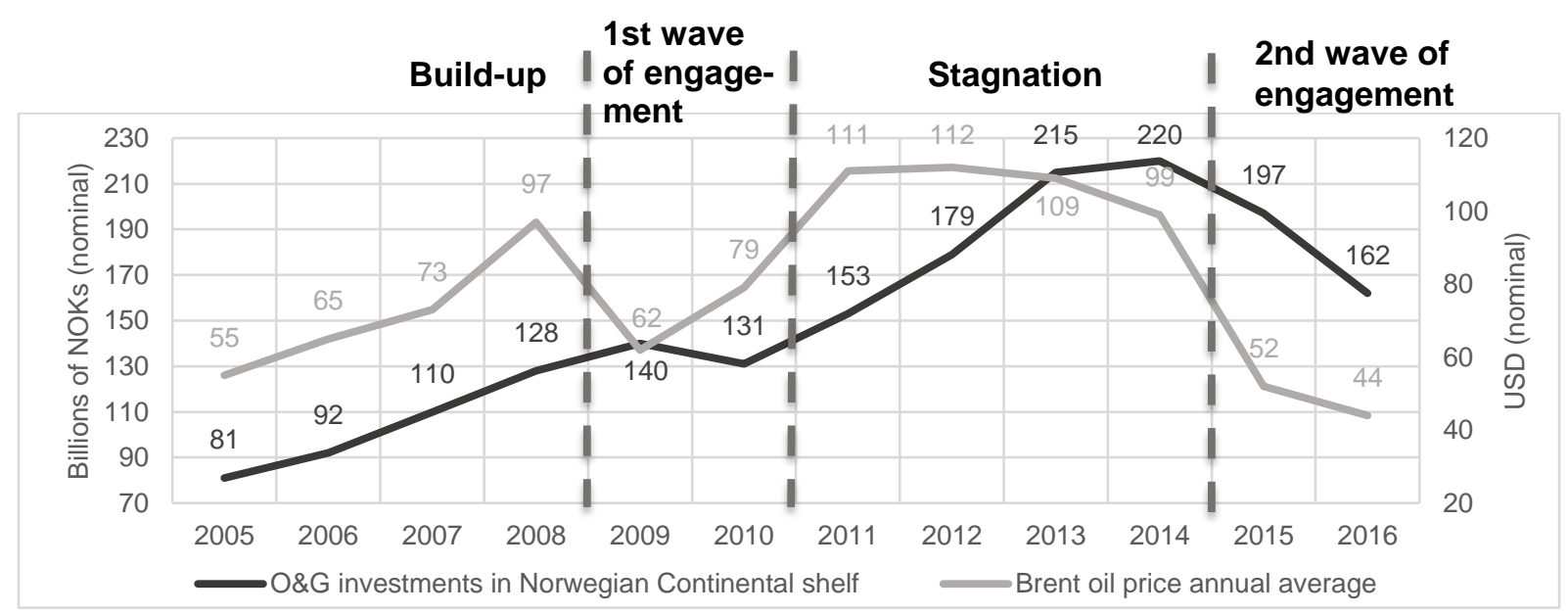

Figure 3 Oil and gas market (SSB, EIA)

During and before the build-up phase, the oil price was increasing. Consequently, even though the new O\&G discoveries had been relatively small, the level of investment in NCS was also increasing 
because high oil prices made even smaller and "exotic" oil fields profitable for O\&G companies. This increased demand in the O\&G industry, making it an attractive market for suppliers.

Following the financial crisis of 2008, growth in the Norwegian O\&G market came to an abrupt end, manifested by the plummeting oil price and decline in investment during the first wave of engagement phase (Figure 3). This significant change in the task environment caused problems in the $O \& G$ industry where many companies had expanded their activities accompanying the market growth, forcing companies to lay off personnel. This also resulted in a growing interest in alternative markets such as OWP (Hansen and Steen, 2015).

During the stagnation phase, increasing oil prices led to an O\&G industry boom in 2011-2014. Moreover, the discovery of two major oil fields in NCS (Johan Sverdrup and Johan Castberg) in 2010-2011 increased expectations for further growth in the market. Following these changes, the director of INTSOK (an O\&G industry organization) stated that few Norwegian suppliers were interested OWP, and the few that had invested in this market wanted to leave in order to refocus on O\&G (TU, 2014).

During the second wave of engagement, a new and more prolonged downturn started with another significant decline in oil prices in the summer of 2014, resulting in a significant downturn in the investment levels in NCS over the next few years (Figure 3). As this downturn lasted longer than the decline of 2009-2010, it had a much stronger impact on the industry, and a significant number of companies went out of business. Moreover, oil companies went through an industry-wide program for increased cost-saving and efficiency (FT, 2016; Sraml Gonzalez, 2018).

\subsubsection{The OWP market}

In addition to the events in the O\&G market, also developments in the OWP market have encouraged firms to explore new opportunities. Measured in annual instalments, the European OWP market experienced a growth trend during 2007-2016 (see Figure 4) (Wind Europe, 2017). 


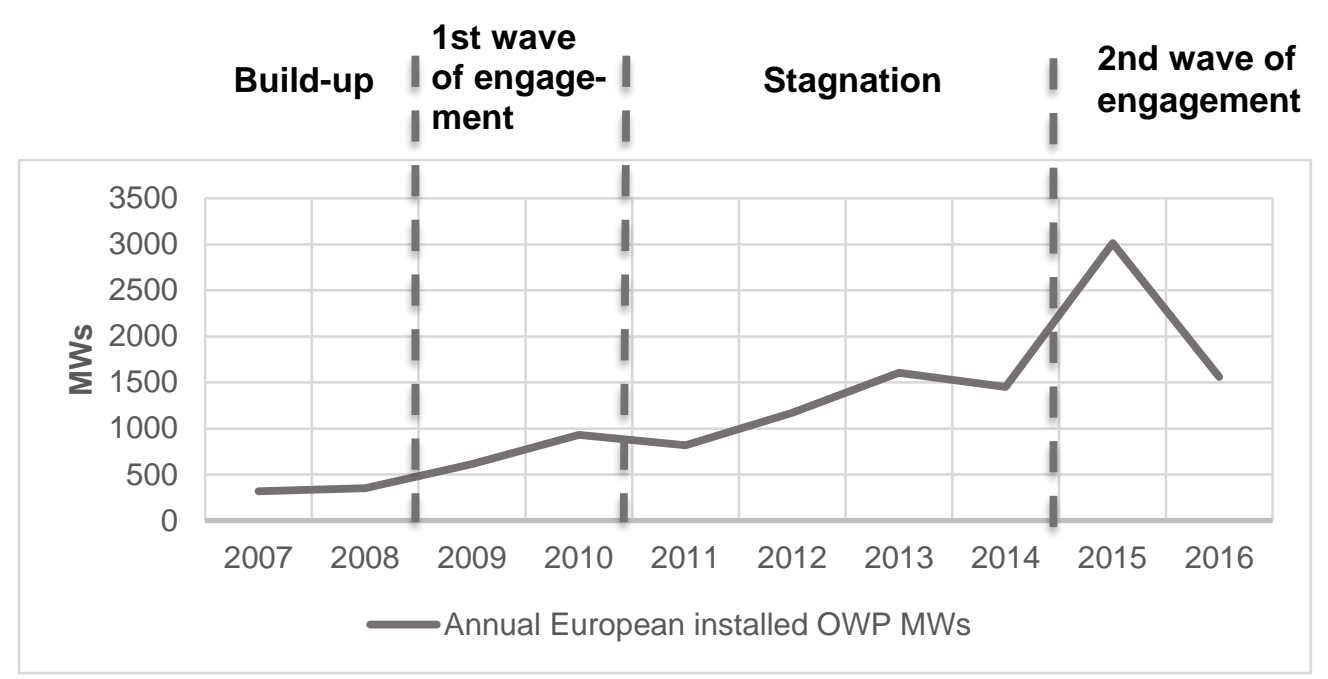

Figure 4 European OWP market (Wind Europe)

Since the early 2000s, the OWP market has developed mainly in the North Sea with Germany, UK, Denmark and the Netherlands as the leading countries (Wieczorek et al., 2013). During the build-up phase, the OWP market was gaining significance. As described by Kern and colleagues (2014), the UK developed in a few years from a "laggard nation" to a leader in OWP deployment, largely stimulated by changes in the Renewables Obligation in 2009 and 2010, which offered greater public support to more expensive technologies such as OWP. Also in Germany, the OWP market began to solidify around 2009 with decisions to implement new projects, despite challenges caused by the financial crisis (Reichardt et al., 2016).

During the stagnation phase, the OWP market continued to grow, especially in the UK, despite the fact that in 2008-2013 the cost of OWP increased due to e.g. high steel price and increased project size and complexity. By the end of the second wave of engagement in 2016, annual investment in OWP was around EUR 18.2 billion (Wind Europe, 2018), exceeding the size of the Norwegian O\&G market. Moreover, the costs of OWP had fallen substantially, and in 2016 developers such as Dong Energy (now Ørsted) and Vattenfall planned to build windfarms at costs well below what was expected only a few years ago (The Telegraph, 14 September 2016).

Seen overall, the OWP market grew rather steadily during 2007-2016. 2015 was the peak year with over $3 \mathrm{GW}$ of OWP coming online in Europe (Wind Europe, 2017). The growing trend in the OWP market and its maturation have therefore made OWP seem like a less risky business opportunity. 


\subsubsection{Summary of task environment and O\&G industry' engagement in OWP}

To enable comparison using different scales, Figure 5 normalizes changes in the task environment and OWP engagement. The O\&G market in particular and the OWP engagement saw major fluctuations. During the stagnation phase, the O\&G market was booming, while OWP engagement was relatively low. In comparison, during the first and second waves of engagement, OWP engagement was high, while the O\&G market was in decline. Meanwhile, the OWP market was on a relatively constant growth path in Europe.

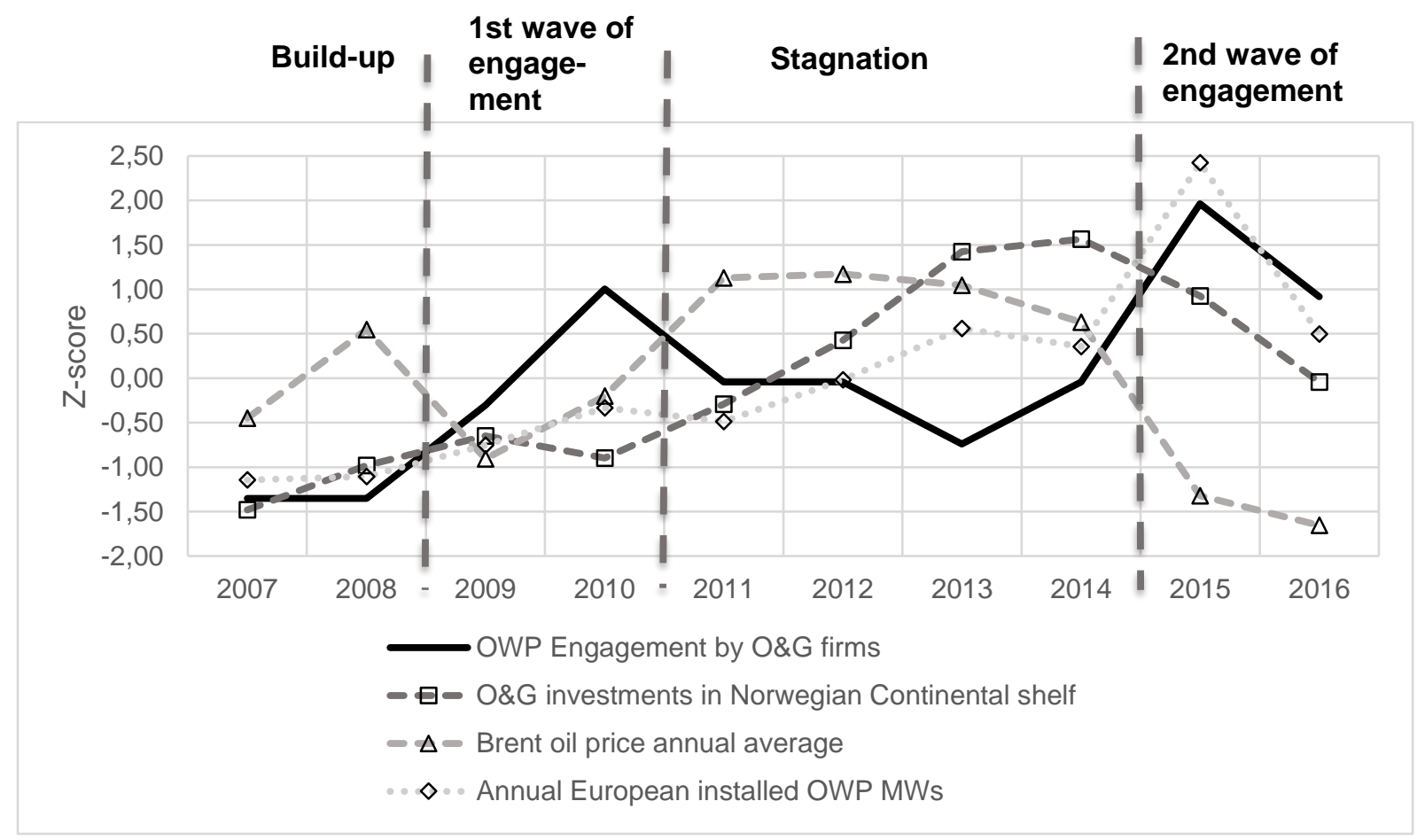

Figure 5 Normalized presentation of task environment and OWP engagement.

\subsection{Developments in the institutional environment}

To address the institutional environment, Figure 6 illustrates the attention in Norwegian newspapers to different framings of the $O \& G$ industry: economic, transition and climate change. The economic framing received more attention after both of the O\&G market declines in 2009 and 2015 when the O\&G industry was undergoing a reduction in labour force. The transition framing, however, began receiving more attention after the market decline in the $O \& G$ industry in 2015. The climate change framing has been a less prevalent issue in comparison to the economic and transition framings. In 
2007, there was heightened attention to the climate change globally as well as in Norway, but in Norway this discussion was mostly detached from discussing the future of the O\&G industry in the country. Hence, the climate change topic appears to have been largely separated from the culturalcognitive understanding of the Norwegian O\&G industry. Figure 6 indicates that until 2015 there was limited attention to topics delegitimizing the $O \& G$ industry in Norway, and instead had been mostly aligned with the favourable economic framing of the O\&G industry. This signifies a stable institutional environment. This may be undergoing a change however, as in the recent years the transition framing, together with the economic framing, have received increased attention.

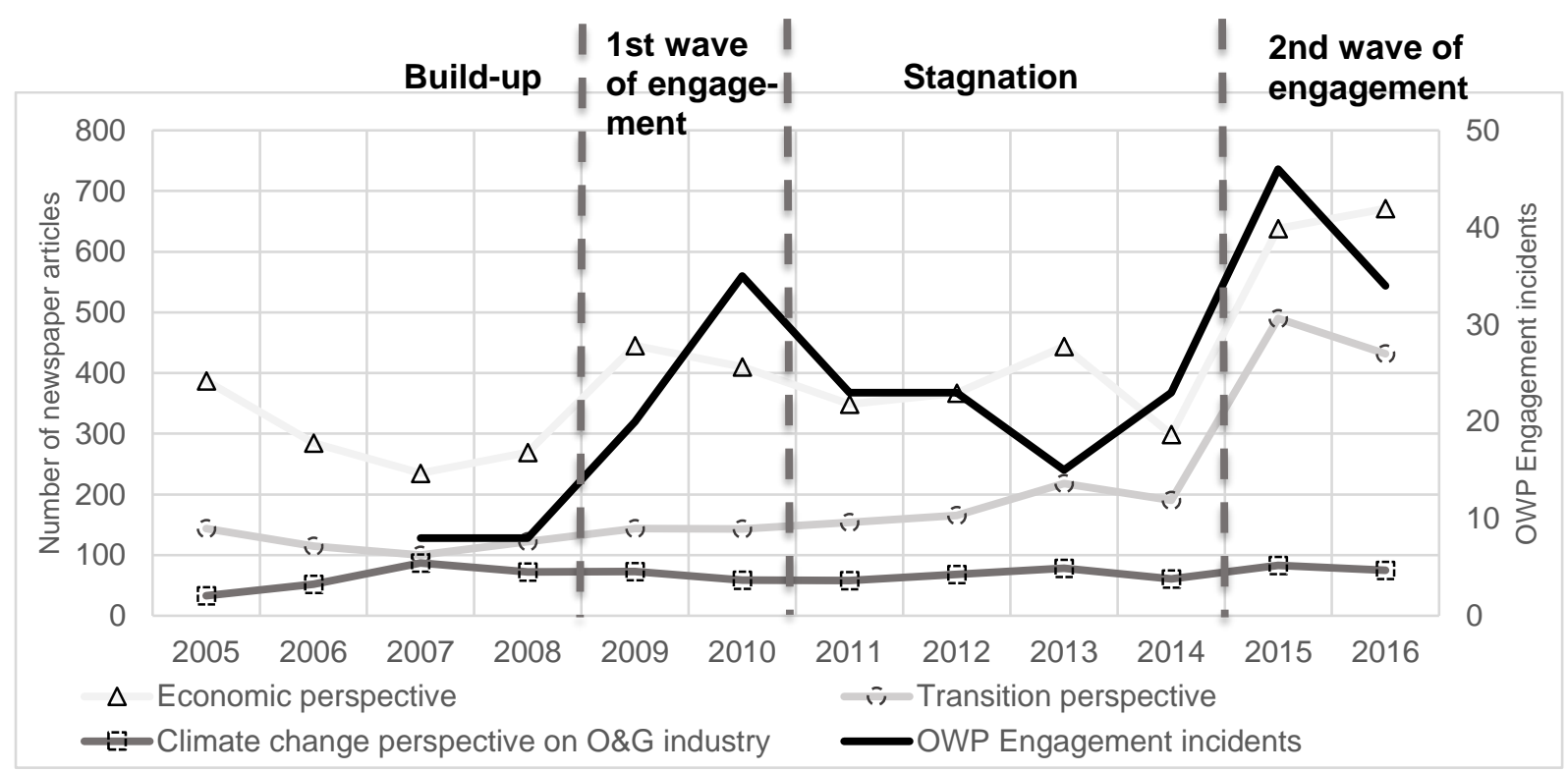

Figure 6 The economic, transition and climate change framings of O\&G industry in six Norwegian newspapers.

Ryggvik and Kristoffersen (2015) argue that historically, in conflicts regarding the pace of oil extraction in Norway, economic interests have prevailed over environmental interests. For instance in 2007-2008, instead of questioning the legitimacy of the O\&G market, awareness of climate change resulted in calls for reductions in emissions and increased investment in renewable energy, including two research centres in OWP. Together with the appointment of a renewable energy enthusiast as the new Minister of Petroleum and Energy in 2007, this created expectations among firms for government-led support for OWP in Norway (Normann, 2015). 
Hence, the institutional environment during the first wave of engagement seemed to favour the development of a Norwegian offshore wind supply industry in this period. The consequences of the decline in the O\&G industry received substantial attention in media and from politicians, and guided attention to how opportunities in OWP could offset some of the layoffs in the O\&G industry (Normann, 2017).

However, in developing an offshore wind industry, the political ambitions did not result in long-term policy measures beyond R\&D support and some short-term relief following the financial crisis. Despite considerable interest and efforts of the industry to lobby the government for supporting the development of a small domestic market, during the stagnation phase these efforts did not lead to such policies due in part to a lack of collective action by OWP supporters (Normann 2015). Another important explanation for the lack of success was also the recovery of the O\&G market. Due to the rising oil prices and the new $O \& G$ discoveries, the level of investments increased and the job situation in the O\&G industry improved. Thus, there was no longer a pressing political problem in which OWP represented a solution, and the political interest in the Norwegian OWP industry faded away (Normann, 2015).

During the stagnation phase, the public legitimacy of the O\&G market remained robust, and was still not significantly challenged, for example, by the climate change concerns. This was illustrated in a 2012 study of the climate change perceptions of the Norwegian public where $68 \%$ of respondents believed climate change to be anthropogenic, but only $23 \%$ agreed that Norway should cease extracting from new oil fields because it contributes to climate change (Austgulen, 2012).

However, during the second wave of engagement, and after the latest O\&G downturn in 2015, there were some signs of change in the cultural-cognitive perception of the $O \& G$ industry in Norway (manifested also in the growing attention to transitions in Figure 6). According to Ryggvik and Kristoffersen (2015), such change include, for example, opposition to oil extraction in the Lofoten and Vesterålen areas, and public statements by notable political persons and organizations emphasizing the potential of green jobs while demanding to leave a large part of Norwegian $O \& G$ in the ground. 
Nevertheless, the increased debate and recognition by politicians that the Norwegian petroleumdependent economy needs to diversify (Regjeringen, 2017) did not lead to changes in policies or regulations which would incentivise firms to redirect resources to other industries, such as OWP (Forskningsrådet, 2017). Instead, continued O\&G activities were supported by opening new concession rounds for O\&G exploration in 2015 and 2017. Regarding political support for OWP, there were no changes in the institutional environment during the second wave of engagement. The continued approach of not investing in a domestic market, but rather support $R \& D$ activities and encouraging export activities, remained the main public policy strategy (Regjeringen, 2016).

\section{Discussion and suggestions for policy}

Literature on sustainable energy transitions hitherto has paid little attention to the reorientations of incumbent energy industries towards sustainability (Geels, 2018). However, pressures and incentives from the industry environment have been suggested to influence such processes (Geels, 2014a, Mignon and Bergek, 2016). The role of organizational environment in a reorientation of fossil fuel industries is therefore an important topic in developing policy measures which can respond to the growing urgency of climate change. We have sought to contribute to such discussions by exploring the engagement of the Norwegian O\&G industry in OWP in the light of developments in the task and institutional environments of the industry.

Our empirical study showed that this engagement fluctuated considerably during 2007-2016. While the institutional environment surrounding the $\mathrm{O} \& \mathrm{G}$ industry remained fairly stable, and the European OWP market was on a growth path, the $\mathrm{O} \& \mathrm{G}$ industry had two peaks of engagement in diversification in OWP - what we call "Green Flings" - separated by a period of lower engagement. These flings occurred simultaneously with two periods of major downturns, and the stagnation in engagement occurred during a boom period in the $\mathrm{O} \& \mathrm{G}$ market. The latter wave of engagement also occurred simultaneous to a peak in 2015 in installed OWP parks. Similarly to Hansen and Steen (2015), our analysis therefore suggests that market changes in $O \& G$ have acted as a key catalyst of engagement in 
OWP. Reduced opportunities in the O\&G market seemed to put pressure on firms to diversify to OWP while the subsequent recovery of the $O \& G$ market drew these firms back to their core market. This behaviour resembles what previous literature has discussed as redeployment of resources between related markets in reaction to uncertainty and changes in the demand in their main market (Bergh and Lawless, 1998, Helfat and Eisenhardt, 2004, Lieberman et al., 2017). Such behaviour was particularly visible in firms with non-scalable resources, such as offshore construction yards and maritime operations companies, which redeployed their vessels and construction capacity to OWP when it was difficult to get contracts in O\&G (Levinthal and Wu, 2010, Wu, 2013, Mäkitie et al., 2018b).

This study has drawn attention to three often-overlooked issues in the study of sustainable energy transitions and related policy topics. First, the study of incumbent industries in energy transition literature has had relatively little focus on the fact that companies are first and foremost concerned with value creation and "making money", where short-term profitability plays an important role. For this reason, rapid changes in the market can also cause rapid responses as firms seek to secure their revenue production by reorganizing their activities to fit market developments (Porter, 1980). Even though incumbent energy industries may resist a fundamental change in the energy market (cf. Geels, 2014b) when subjected to economic pressures, the supply side of the industry in particular may perform a relatively fast reorientation towards other markets such as renewables. This was visible in our case study where some $O \& G$ supplier firms almost immediately increased their engagement in OWP when their core market ran into trouble. In comparison, the institutional environment remained relatively stable during the period studied. In fact, the short period of favourable political conditions for reorientation to OWP in 2009-2010 was related to the O\&G market downturn occurring at the same time.

In sum, it was therefore apparent that the developments in the institutional environment or in the OWP market could not explain the observed "flings". This leads us to argue that changes in the core O\&G market of the industry have played a more important role in influencing the degree of reorientation to OWP. Hence, we further argue that policy measures addressing the economic environment and the economic situation of incumbent energy industries can have an effective and swift impact in causing a 
reorientation towards renewable energy markets. Such findings support the recent argument made by Kivimaa and Kern (2016) that destabilizing policy measures (e.g. through regulation) directed towards the market conditions of the incumbent energy industries can help accelerating sustainable energy transitions. In relation to our case study, such policy measures could include, for example, halting the opening of new O\&G exploration blocks, and rolling back subsidy schemes related to the O\&G market. Through nationally owned companies like Equinor, the state could also influence the pace of reorientation in such companies, which would encourage suppliers to move to new markets as well.

Second, as noted also by Geels and Penna (2015), when incumbent industry reorientation is triggered by the environment, this engagement can also backtrack when external pressure diminishes. This was certainly visible in our study when the $O \& G$ industry, particularly suppliers, reduced engagement in OWP during a boom period in the O\&G market, even though in the meantime also the OWP market continued to grow. This finding draws attention to the possible reversibility of industry reorientations (cf. Pinkse and van den Buuse, 2012). Our results suggest that several firms in the O\&G industry redeployed resources back to $O \& G$ at the expense of OWP once the pressure from the economic environment declined. Such "on-off relationships" or green flings of incumbent energy industries are likely to be harmful for the long-term development of new renewable energy industries. It is therefore important that policy measures signal a long-term public commitment towards industry diversification, and do not merely respond to sudden developments in the task environment of the incumbent industries.

Third, the relatively fast reorientation of O\&G industry towards OWP showed that at least part of the industry was able use their existing competences and other resources in another market. We therefore suggest that redeployment of resources can be a key factor in enabling more effective reorientation of fossil fuel industries towards renewable energy. Engagement of incumbent energy industries may also speed up transitions through the redeployment of financial resources, engineering capabilities, technologies etc. in renewable energy industries (Hanson, 2017). 
We are mindful that our study has some shortcomings that need to be addressed in further research. First, we recognise that also other things than environmental factors can explain diversification. For instance, public relations opportunities and other types of pressures and expectations to appear legitimate may affect such decisions, as well as internal organizational factors, such as the organization structure and the corporate culture of firms (Kolk and Levy, 2001, Levy and Kolk, 2002, Hansen and Steen, 2015, Normann, 2015). Moreover, especially large and affluent oil companies can choose to diversify to new and also unrelated markets without significant influence from the environment. For instance, Equinor seems to have made the strategic decision to diversify to renewables apparently irrespective of the external economic pressures, while for instance BP and Shell have developed solar PV technologies, which are technologically unrelated to oil and gas (Pinkse and van den Buuse, 2012).

Second, our analysis was limited to a single country, Norway. We are therefore uncertain whether the O\&G industry behaviour would have been similar in other countries. We therefore call for further studies using similar research design in other countries, or studies comparing incumbent energy industries in multiple countries.

Third, we have relied to a large extent on news data to trace the engagement in OWP. We are dependent on media outlets, journalists and firms in their decisions to report on the O\&G industry's engagement in OWP; this can cause a bias in our data material. We have sought to overcome this weakness by using different data sources in identifying engagement incidents. The most important drawback is that firms are more likely to report entry decisions, and our dataset therefore has very few observations of exit behaviour from OWP.

We conclude by calling for further studies in the field of sustainable energy transition literature to empirically investigate incumbent energy industries in sustainable energy transitions. Moreover, we encourage further study of intermittency in industry reorientation in order to support energy transitions policy-making. Finally, we call for further conceptual development regarding the issue of resource 
redeployment between established and emerging industries in the context of sustainable energy

transitions.

\section{Acknowledgements}

We would like thank the two anonymous referees for their constructive and insightful comments.

Moreover, we would like to thank Keith Smith for his contribution in formulating the research topic, and Anna Bergek, Jens Hanson, Olav Wicken, Bjørn Asheim, Mette Talseth Solnørdal, Susanne Bauer, Kristin Asdal and Artur Santoalha for their valuable comments on earlier versions of this paper. This work was supported by the Research Council of Norway (grant numbers 237677, 209697).

\section{References}

ACHA, V. \& CUSMANO, L. 2005. Governance and co-ordination of distributed innovation processes: patterns of R\&D co-operation in the upstream petroleum industry. Economics of Innovation and New Technology, 14, 1-21.

AUSTGULEN, M. H. 2012. Nordmenns holdninger til klimaendringer, medier og politikk. Prosjektnotat nr. 4-2012. Oslo: SIFO.

BARNEY, J. 1991. Firm resources and sustained competitive advantage. Journal of Management, 17, 99.

BERGEK, A., BERGGREN, C., MAGNUSSON, T. \& HOBDAY, M. 2013. Technological discontinuities and the challenge for incumbent firms: Destruction, disruption or creative accumulation? Research Policy, 42, 1210-1224.

BERGH, D. D. 1998. Product-market uncertainty, portfolio restructuring, and performance: An information-processing and resource-based view. Journal of Management, 24, 135-155.

BERGH, D. D. \& LAWLESS, M. W. 1998. Portfolio Restructuring and Limits to Hierarchical Governance: The Effects of Environmental Uncertainty and Diversification Strategy. Organization Science, 9, 87-102.

BLOMGREN, A., QUALE, C., AUSTNES-UNDERHAUG, R., HARSTAD, A. M., FJOSE, S., WIFSTAD, K., MELLBYE, C., AMBLE, I. B., NYVOLD, C. E., STEFFENSEN, T., VIGGEN, J. R., IGLEB/EK, F., ARNESEN, T. \& ERIK, H. S. 2015. Industribyggerne 2015. Rapport IRIS. IRIS.

BRESCHI, S., LISSONI, F. \& MALERBA, F. 2003. Knowledge-relatedness in firm technological diversification. Research Policy, 32, 69-87.

CARROLL, G. R., BIGELOW, L. S., SEIDEL, M.-D. L. \& TSAI, L. B. 1996. The fates of de novo and de alio producers in the American automobile industry 1885-1981. Strategic Management Journal, 17, 117-137.

CHAIYAPA, W., ESTEBAN, M. \& KAMEYAMA, Y. 2018. Why go green? Discourse analysis of motivations for Thailand's oil and gas companies to invest in renewable energy. Energy Policy, 120, 448-459. 
DAHL, R. E. \& OSMUNDSEN, P. 2014. Estimating Fluctuations in Oil and Gas Investment. CESifo working paper no. 5011 Category 9: resource and environment economics LudwigMaximilians University CESifo.

EISENHARDT, K. M. \& MARTIN, J. A. 2000. Dynamic capabilities: what are they? Strategic Management Journal, 21, 1105-1121.

FLIGSTEIN, N. \& MARA-DRITA, I. 1996. How to Make a Market: Reflections on the Attempt to Create a Single Market in the European Union. American Journal of Sociology, 102, 1-33.

FORSKNINGSRÅDET 2017. Det norske forsknings- og innovasjonssystemet - statistikk og indikatorer. Oslo: The Research Council of Norway.

GEELS, F. W. 2014a. Reconceptualising the co-evolution of firms-in-industries and their environments: Developing an inter-disciplinary Triple Embeddedness Framework. Research Policy, 43, 261-277.

GEELS, F. W. 2014b. Regime Resistance against Low-Carbon Transitions: Introducing Politics and Power into the Multi-Level Perspective. Theory, Culture \& Society, 31, 21-40.

GEELS, F. W. 2018. Disruption and low-carbon system transformation: Progress and new challenges in socio-technical transitions research and the Multi-Level Perspective. Energy Research \& Social Science, 37, 224-231.

GEELS, F. W. \& PENNA, C. C. R. 2015. Societal problems and industry reorientation: Elaborating the Dialectic Issue LifeCycle (DILC) model and a case study of car safety in the USA (1900-1995). Research Policy, 44, 67-82.

GRANT, R. M. 2003. Strategic planning in a turbulent environment: evidence from the oil majors. Strategic Management Journal, 24, 491-517.

HANSEN, G. H. \& STEEN, M. 2015. Offshore oil and gas firms' involvement in offshore wind: Technological frames and undercurrents. Environmental Innovation and Societal Transitions, 17, 1-14.

HANSON, J. 2017. Established industries as foundations for emerging technological innovation systems: The case of solar photovoltaics in Norway. Environmental Innovation and Societal Transitions.

HELFAT, C. E. \& EISENHARDT, K. M. 2004. Inter-temporal economies of scope, organizational modularity, and the dynamics of diversification. Strategic Management Journal, 25, 12171232.

IHLEN, $\varnothing$. \& NITZ, M. 2008. Framing Contests in Environmental Disputes: Paying Attention to Media and Cultural Master Frames. International Journal of Strategic Communication, 2, 1-18.

JACOBSSON, S. \& LAUBER, V. 2006. The politics and policy of energy system transformationexplaining the German diffusion of renewable energy technology. Energy Policy, 34, 256-276.

KERN, F., SMITH, A., SHAW, C., RAVEN, R. \& VERHEES, B. 2014. From laggard to leader: Explaining offshore wind developments in the UK. Energy Policy, 69, 635-646.

KIVIMAA, P. \& KERN, F. 2016. Creative destruction or mere niche support? Innovation policy mixes for sustainability transitions. Research Policy, 45, 205-217.

KOLK, A. \& LEVY, D. 2001. Winds of Change:: Corporate Strategy, Climate change and Oil Multinationals. European Management Journal, 19, 501-509.

LANGLEY, A. 1999. Strategies for Theorizing from Process Data. The Academy of Management Review, 24, 691-710.

LEVINTHAL, D. A. \& WU, B. 2010. Opportunity costs and non-scale free capabilities: profit maximization, corporate scope, and profit margins. Strategic Management Journal, 31, 780 801.

LEVY, D. L. \& KOLK, A. 2002. Strategic Responses to Global Climate Change: Conflicting Pressures on Multinationals in the Oil Industry. Business and Politics, 4, 275-300.

LIEBERMAN, M. B., LEE, G. K. \& FOLTA, T. B. 2017. Entry, exit, and the potential for resource redeployment. Strategic Management Journal, 38, 526-544.

MAHON, J. F. \& WADDOCK, S. A. 1992. Strategic Issues Management: An Integration of Issue Life Cycle Perspectives. Business \& Society, 31, 19-32. 
MIGNON, I. \& BERGEK, A. 2016. Investments in renewable electricity production: The importance of policy revisited. Renewable Energy, 88, 307-316.

MOHN, K. 2010. Elastic Oil: A Primer on the Economics of Exploration and Production. In: BJØRNDAL, E., BJØRNDAL, M., PARDALOS, M. P. \& RÖNNQVIST, M. (eds.) Energy, Natural Resources and Environmental Economics. Berlin, Heidelberg: Springer Berlin Heidelberg.

MOHN, K. \& MISUND, B. 2009. Investment and uncertainty in the international oil and gas industry. Energy Economics, 31, 240-248.

MÄKITIE, T., ANDERSEN, A. D., HANSON, J., NORMANN, H. E. \& THUNE, T. M. 2018a. Established sectors expediting clean technology industries? The Norwegian oil and gas sector's influence on offshore wind power. Journal of Cleaner Production, 177, 813-823.

MÄKITIE, T., THUNE, T. M. \& SRAML GONZALEZ, J. 2018b. Chapter 13. From oil to wind, and back again: Resource redeployment and diversification. In: THUNE, T. M., ENGEN, O. A. \& WICKEN, O. (eds.) Petroleum Industry Transformations: Lessons from Norway and Beyond. Routledge.

NAYYAR, P. \& KAZANJIAN, R. 1993. Organizing to attain potential benefits from information asymmetries and economies of scope in related diversified firms. Academy of Management. The Academy of Management Review, 18, 735.

NEWELL, P. \& PATERSON, M. 1998. A Climate for Business: Global Warming, the State and Capital. Review of International Political Economy, 5, 679-703.

NORMANN, H. E. 2015. The role of politics in sustainable transitions: The rise and decline of offshore wind in Norway. Environmental Innovation and Societal Transitions, 15, 180-193.

NORMANN, H. E. 2017. Policy networks in energy transitions: The cases of carbon capture and storage and offshore wind in Norway. Technological Forecasting and Social Change, 118, 80 93.

NORMANN, H. E. \& HANSON, J. 2015. Exploiting global renewable energy growth. Opportunities and challenges for internationalisation in the Norwegian offshore wind and solar energy industries. Centre for sustainable Energy Studies.

NORMANN, H. E. \& HANSON, J. 2018. The role of domestic markets in international technological innovation systems. Industry and Innovation, 25, 482-504.

PENNA, C. C. R. \& GEELS, F. W. 2012. Multi-dimensional struggles in the greening of industry: A dialectic issue lifecycle model and case study. Technological Forecasting \& Social Change, 79, 999-1020.

PENNA, C. C. R. \& GEELS, F. W. 2015. Climate change and the slow reorientation of the American car industry (1979-2012): An application and extension of the Dialectic Issue LifeCycle (DILC) model. Research Policy, 44, 1029-1048.

PENROSE, E. 1959. The theory of the growth of the firm, Oxford, Blackwell.

PERRONS, R. K. 2014. How innovation and R\&D happen in the upstream oil \& gas industry: Insights from a global survey. Journal of Petroleum Science and Engineering, 124, 301-312.

PINCH, T. \& BIJKER, W. E. 1987. The Social Construction of Facts and Artifacts: Or How the Sociology of Science and the Sociology of Technology Might Benefit Each Other. In: BIJKER, W. E., HUGHES, T. P. \& PINCH, T. (eds.) The Social Construction of Technological Systems. New Directions in the Sociology and History of Technology. Cambridge, Massachusetts: The MIT Press.

PINKSE, J. \& VAN DEN BUUSE, D. 2012. The development and commercialization of solar PV technology in the oil industry. Energy Policy, 40, 11-20.

PISANO, G. P. 2017. Toward a prescriptive theory of dynamic capabilities: connecting strategic choice, learning, and competition. Industrial and Corporate Change, 26, 747-762.

PORTER, M. E. 1980. Competitive strategy : techniques for analyzing industries and competitors, New York, Free Press.

REGJERINGEN 2016. Meld. St. 25 (2015-2016). Melding til Stortinget. Kraft til endring. Energipolitikken mot 2030. In: ENERGIDEPARTMENT, D. K. O.-O. (ed.).

REGJERINGEN 2017. Meld. St.29 (2016-2017). Melding til Stortinget. Perspektivmeldingen 2017. In: FINANSDEPARTEMENT, D. K. (ed.). 
REICHARDT, K., NEGRO, S. O., ROGGE, K. S. \& HEKKERT, M. P. 2016. Analyzing interdependencies between policy mixes and technological innovation systems: The case of offshore wind in Germany. Technological Forecasting and Social Change, 106, 11-21.

RYGGVIK, H. \& KRISTOFFERSEN, B. 2015. Heating Up and Cooling Down the Petrostate: The Norwegian Experience. In: PRINCEN, T., MANNO, J. P. \& MARTIN, P. L. (eds.) Ending the Fossil Fuel Era. The MIT Press.

SAKHARTOV, A. V. \& FOLTA, T. B. 2015. Getting beyond relatedness as a driver of corporate value. Strategic Management Journal, 36, 1939-1959.

SCIENTIFIC AMERICAN. 2018. Global CO2 Emissions Rise after Paris Climate Agreement Signed [Online]. Scientific American. Available: https://www.scientificamerican.com/article/globalco2-emissions-rise-after-paris-climate-agreement-signed/ [Accessed 17 October 2018].

SCOTT, W. R. 2003. Organizations : rational, natural, and open systems, Upper Saddle River, N.J, Prentice Hall Pearson Education International.

SCOTT, W. R. 2014. Institutions and organizations : ideas, interests, and identities, Thousand Oaks, Calif, Sage.

SRAML GONZALEZ, J. 2018. Innovation in situations of crisis. Oil and gas suppliers as innovators during the 2014-2017 industry downturn. Doctoral dissertation, University of Oslo.

STEEN, M. \& KARLSEN, A. 2014. Path creation in a single-industry town: The case of Verdal and Windcluster Mid-Norway. Norsk Geografisk Tidsskrift - Norwegian Journal of Geography, 68, 133-143.

STEEN, M. \& WEAVER, T. 2017. Incumbents' diversification and cross-sectorial energy industry dynamics. Research Policy, 46, 1071-1086.

SUAREZ, F. F. \& OLIVA, R. 2005. Environmental change and organizational transformation. Industrial and Corporate Change, 14, 1017-1041.

TANRIVERDI, H. \& VENKATRAMAN, N. 2005. Knowledge relatedness and the performance of multibusiness firms. Strategic Management Journal, 26, 97-119.

TEECE, D. J., PISANO, G. \& SHUEN, A. 1997. Dynamic capabilities and strategic management. Strategic Management Journal, 18, 509-533.

THUNE, T. \& MÄKITIE, T. 2018. Chapter 11. Versatile competences and product market diversification among oil and gas supply firms. In: THUNE, T., ENGEN, O. A. \& WICKEN, O. (eds.) Petroleum Industry Transformations: Lessons from Norway and Beyond. Routledge.

THUNE, T., WICKEN, O. \& ENGEN, O. A. 2018. Petroleum industry transformations : lessons from Norway and beyond, London, Routledge.

TU. 2014. Nå sier leverandørindustrien nei takk til havvind [Online]. Teknisk Ukeblad. Available: https://www.tu.no/artikler/na-sier-leverandorindustrien-nei-takk-til-havvind/231345 [Accessed 24 September 2018].

TURNHEIM, B. \& GEELS, F. W. 2012. Regime destabilisation as the flipside of energy transitions: Lessons from the history of the British coal industry (1913-1997). Energy Policy, 50, 35-49.

TUSHMAN, M. L. \& ANDERSON, P. 1986. Technological Discontinuities and Organizational Environments. Administrative Science Quarterly, 31, 439-465.

TVEDT, J. 2002. The effect of uncertainty and aggregate investments on crude oil price dynamics. Energy Economics, 24, 615-628.

UNRUH, G. C. 2000. Understanding carbon lock-in. Energy Policy, 28, 817-830.

VAN DE VEN, A. H. 1992. Suggestions for studying strategy process: A research note. Strategic Management Journal, 13, 169-188.

VAN DE VEN, A. H. 2007. Engaged Scholarship. A guide for organizational and social research, United Kingdom, Oxford University Press.

VAN DEN HOVE, S., LE MENESTREL, M. \& DE BETTIGNIES, H.-C. 2002. The oil industry and climate change: strategies and ethical dilemmas. Climate Policy, 2, 3-18.

WIECZOREK, A. J., NEGRO, S. O., HARMSEN, R., HEIMERIKS, G. J., LUO, L. \& HEKKERT, M. P. 2013. A review of the European offshore wind innovation system. Renewable and Sustainable Energy Reviews, 26, 294-306. 
WIND EUROPE 2017. The European offshore wind industry. Key trends and statistics 2016.: Wind Europe.

WIND EUROPE 2018. Offshore Wind in Europe. Key trends and statistics 2017.

WU, B. 2013. Opportunity costs, industry dynamics, and corporate diversification: Evidence from the cardiovascular medical device industry, 1976-2004. Strategic Management Journal, 34, 1265-1287. 